\title{
East Siberian Sea, an Arctic region of very high biogeochemical activity
}

\author{
L. G. Anderson ${ }^{1}$, G. Björk ${ }^{2}$, S. Jutterström ${ }^{1,3}$, I. Pipko ${ }^{4}$, N. Shakhova ${ }^{4,5}$, I. Semiletov ${ }^{4,5}$, and I. Wåhlström ${ }^{1}$ \\ ${ }^{1}$ Department of Chemistry, University of Gothenburg, Sweden \\ ${ }^{2}$ Department of Geosciences, University of Gothenburg, Sweden \\ ${ }^{3}$ Bjerknes Centre for Climate Research, UNIFOB AS, Bergen, Norway \\ ${ }^{4}$ Pacific Oceanological Institute FEB RAS, Vladivostok, Russian Federation \\ ${ }^{5}$ International Arctic Research Center/University Alaska, Fairbanks, USA
}

Received: 18 January 2011 - Published in Biogeosciences Discuss.: 8 February 2011

Revised: 2 June 2011 - Accepted: 15 June 2011 - Published: 30 June 2011

\begin{abstract}
Shelf seas are among the most active biogeochemical marine environments and the East Siberian Sea is a prime example. This sea is supplied by seawater from both the Atlantic and Pacific Oceans and has a substantial input of river runoff. All of these waters contribute chemical constituents, dissolved and particulate, but of different signatures. Sea ice formation during the winter season and melting in the summer has a major impact on physical as well as biogeochemical conditions. The internal circulation and water mass distribution is significantly influenced by the atmospheric pressure field. The western region is dominated by input of river runoff from the Laptev Sea and an extensive input of terrestrial organic matter. The microbial decay of this organic matter produces carbon dioxide $\left(\mathrm{CO}_{2}\right)$ that oversaturates all waters from the surface to bottom relative to atmospheric level, even when primary production, inferred from low surface water nutrients, has occurred. The eastern surface waters were under-saturated with respect to $\mathrm{CO}_{2}$ illustrating the dominance of marine primary production. The drawdown of dissolved inorganic carbon equals a primary production of $\sim 0.8 \pm 2 \mathrm{~mol} \mathrm{C} \mathrm{m}^{-2}$, which when multiplied by half the area of the East Siberian Sea, $\sim 500000 \mathrm{~km}^{2}$, results in an annual primary production of $0.4( \pm 1) \times 10^{12} \mathrm{~mol} \mathrm{C}$ or $\sim 4$ $( \pm 10) \times 10^{12} \mathrm{gC}$. Microbial decay occurs through much of the water column, but dominates at the sediment interface where the majority of organic matter ends up, thus more of the decay products are recycled to the bottom water. High nutrient concentrations and fugacity of $\mathrm{CO}_{2}$ and low oxygen and $\mathrm{pH}$ were observed in the bottom waters. Another signature of organic matter decomposition, methane $\left(\mathrm{CH}_{4}\right)$, was
\end{abstract}

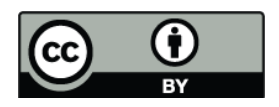

Correspondence to: L. G. Anderson (leifand@chem.gu.se) observed in very high but variable concentrations. This is due to its seabed sources of glacial origin or modern production from ancient organic matter, becoming available due to sub-sea permafrost thaw and formation of so-called taliks. The decay of organic matter to $\mathrm{CO}_{2}$ as well as oxidation of $\mathrm{CH}_{4}$ to $\mathrm{CO}_{2}$ contribute to a natural ocean acidification making the saturation state of calcium carbonate low, resulting in under-saturation of all the bottom waters with respect to aragonite and large areas of under-saturation down to $50 \%$ with respect to calcite. Hence, conditions for calcifying organisms are very unfavorable.

\section{Introduction}

The East Siberian Sea (ESS) is the widest of the Arctic Ocean shelf seas, with an area of $89510^{3} \mathrm{~km}^{2}$, but as the mean depth is only $52 \mathrm{~m}$ it has the smallest volume after the Chukchi Sea (Jakobsson, 2002). From a hydrographic point it is a transit area with seawater of Pacific origin entering from the east and water of Atlantic origin entering from the west. However, Atlantic water entering in the western regions of the East Siberian Sea are heavily diluted by upstream river runoff, specifically the Lena River, even before entering the ESS. In addition, river runoff is also added directly into the ESS from the Indigirka and Kolyma rivers with mean annual discharges of $50.6 \mathrm{~km}^{3}$ for period $1936-1998$ and $102.7 \mathrm{~km}^{3}$ for period 1978-2000, respectively (http://rims.unh.edu/).

The fresh water content of the ESS is high, especially in the western area (Steele and Ermold, 2004), but its momentary spatial distribution is largely dependent on the wind and is controlled by the atmospheric pressure pattern. There is a clear tendency of having less fresh water in the eastern part

Published by Copernicus Publications on behalf of the European Geosciences Union. 


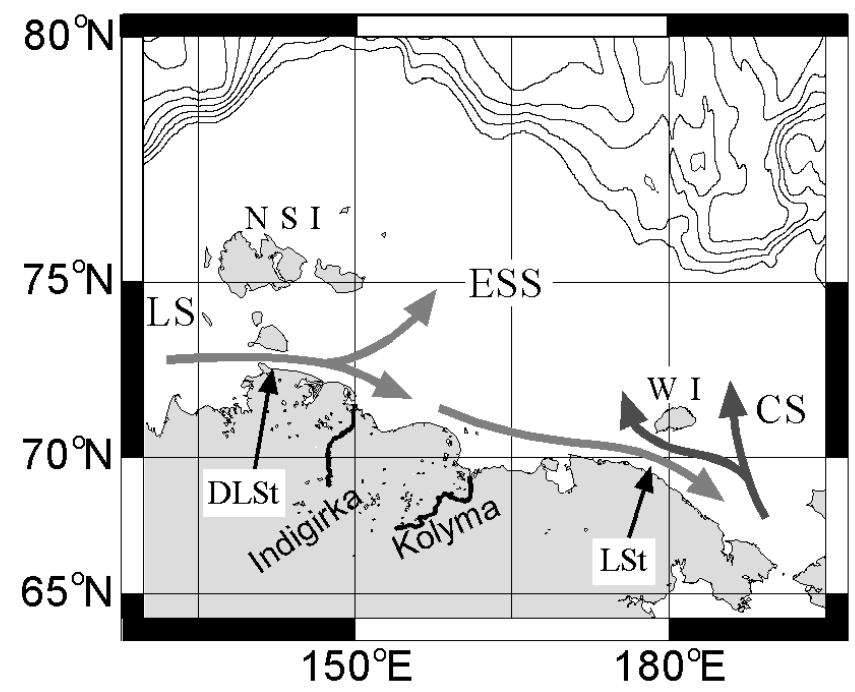

Fig. 1. Map of the East Siberian Sea with illustration of the Siberian Costal Current following the coast to the east and the inflow of low salinity water from the Laptev Sea (LS) to the northwest of the ESS and the inflow of water from the Chukchi Sea (CS) to the northeast of the ESS. The mouth of the two largest rivers, Indigirka and Kolyma, entering the ESS are noted, as well as the New Siberian Islands (NSI), Wrangel Island (WI), Dmitry Laptev Strait (DLSt) and Long Strait (LSt).

during summers with dominant high pressure in the central Arctic (anticyclonic circulation) and vice versa for the low pressure situation (cyclonic circulation) (Dmitrenko et al., 2005; Dmitrenko et al., 2008). Significant long term changes of the freshwater content as seen in the historical data record has been explained by variations in river discharge combined with changes in the atmospheric circulation (Polyakov et al., 2008). The sea ice motion is also affected by the wind pattern resulting in sea ice generally moving in the wind direction, except within the near shore zone during winter when stationary land fast ice is present (Morris et al., 1999; Holt and Martin, 2001). The large decrease in the Arctic Ocean summer sea ice coverage observed during latter years has made the ESS going from an area being largely ice covered in the summer to one now largely ice free (Nghiem et al., 2006; Kwok et al., 2009).

The current system in the ESS is controlled both by the strong baroclinic forcing by river runoff and by wind (Fig. 1). The river runoff promotes development of the low salinity Siberian Coastal Current (SCC) following the coast from the west to the east (e.g., Weingartner et al., 1999). However, the wind forcing makes the ESS highly variable. The SCC was focused as a narrow jet along the coast under cyclonic atmospheric conditions in the summer-fall of 2003, while in 2004, with anticyclonic atmospheric circulation it was less confined as reported by (Savel'eva et al., 2008) and was not present at all in the Chukchi Sea east of ESS (Weingartner et al., 1999). The SCC often extends all the way into the
Chukchi Sea, where it mixes with the northward flow from the Bering Strait. Between the SCC and the Wrangel Island, seawater from the Chukchi Sea, with its high nutrient signature, enters the ESS (e.g., Codispoti and Richards, 1968).

Seawater temperature is generally close to the freezing point over the entire water column during winter as a result of surface cooling and ice formation. During summer the temperature raises to several degrees above zero near the surface in ice free areas. The bottom layer may well be affected by intrusions of warmer Atlantic water coming from the continental slope during upwelling conditions (Dmitrenko et al., 2010)

The information on the biogeochemical environment of the ESS is limited, but some studies have been performed along the coast. Codispoti and Richards (1968) concluded that the nutrient distribution was impacted by primary production in summer, respiration of organic matter, and the origin of the high salinity water. The latter was suggested to be inflow from the Pacific Ocean through the Bering Strait, based on the high nutrient concentrations, specifically phosphate. Khim et al. (2003) used $\delta^{18} \mathrm{O}$ and $\delta^{13} \mathrm{C}$ to deduce the distribution of freshwater in the water column and terrestrial $\mathrm{OM}$ in the sediment. They concluded that the runoff signal could be traced more than $50 \mathrm{~km}$ off shore even in the end of summer, about 2 month after the peak river discharge. The terrestrial OM signal was substantial close to the coast all from the western Chukchi Sea towards the west, but decreased off shore. Semiletov et al. (2005) divided the ESS into two specific areas based on water properties and geochemical data from the sediment surface collected in an area reaching from the coast and up to $\sim 100 \mathrm{~km}$ outwards. Furthermore the waters in the western near shore zone of the ESS have been shown to be a strong source of atmospheric $\mathrm{CO}_{2}$, possibly increasing due to added input of terrestrial organic matter from permafrost thawing (Pipko et al., 2005, 2008; Semiletov et al., 2007; Anderson et al., 2009).

In the summer of 2008 (15 August to 26 September) the International Siberian Shelf Study (ISSS-08) was conducted with the objective to investigate the flux and transformation of carbon from land over the shelf seas and into the deep central basins of the Arctic Ocean. An extensive sampling program was undertaken on board the Russian vessel Yacob Smirnitskyi in the waters of the Laptev, East Siberian and Chukchi Seas. This study of the East Siberian Sea is by far the most comprehensive collection of biogeochemical data and in this contribution we analyze them with the aim of elucidating relevant biogeochemical processes, including the magnitude of primary production, and the decay of organic matter as well as its impact on ocean acidification.

\section{Methods}

57 stations were occupied in the ESS between the $31 \mathrm{Au}-$ gust and 15 September 2008 (Fig. 2a). A SeaBird 911+ CTD system was attached to a 12 bottle rosette system 


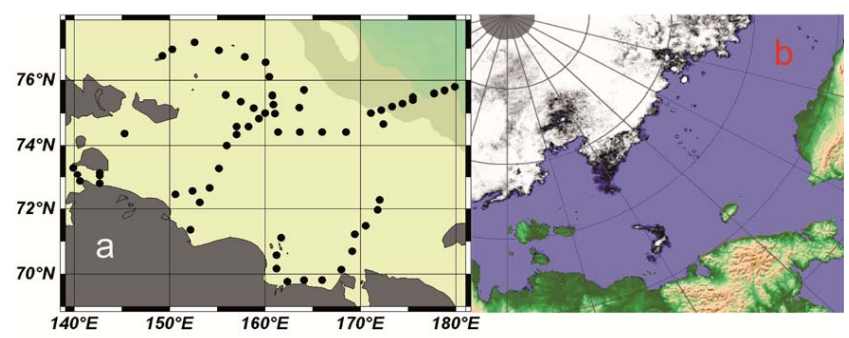

Fig. 2. Map with station positions in the ESS (a) and sea ice coverage on 7 September 2008 (b), Spreen et al. (2008); http: //www.iup.uni-bremen.de:8084/amsr/amsre.html.

for water sample collection. The salinity data was calibrated against water samples analysed onboard using an AUTOSAL lab-salinometer on about half of the collected water samples. Depth profiles of nutrients, oxygen, $\mathrm{pH}$, total alkalinity (TA) and dissolved inorganic carbon (DIC) were collected and determined in a container laboratory on board using state of the art analytical techniques. $\mathrm{Nu}-$ trients, phosphate, nitrate and silicate were determined by a SmartChem analyzer (Westco Scientific Instruments Inc.; http://www.westcoscientific.com/pages/smartchem200. htm\#applications). The samples were filtered before analysis and evaluated by a 6 to 8-points calibration curve, precision being $\sim 1 \%$. Oxygen was determined using an automatic Winkler titration system, giving a precision of $\sim 1 \mu \mathrm{mol} \mathrm{kg}{ }^{-1}$.

DIC was determined by a coulometric titration method based on Johnson et al. (1987), having a precision of $\sim 2 \mu \mathrm{mol} \mathrm{kg}{ }^{-1}$, with the accuracy set by calibration against certified reference materials (CRM), supplied by A. Dickson, Scripps Institution of Oceanography (USA). TA was determined by potentiometric titration, precision $\sim 2 \mu \mathrm{mol} \mathrm{kg}{ }^{-1}$, (Haraldsson et al., 1997) with the accuracy set the same way as for DIC. $\mathrm{pH}$ was determined by spectrophotometric detection (Clayton and Byrne, 1993; Lee and Millero, 1995), having a precision of $\sim 0.003 \mathrm{pH}$ units and the accuracy was set by the equilibrium constants of the indicator. The values presented are on the seawater scale and are normalized to a temperature of $15^{\circ} \mathrm{C}$ and atmospheric pressure.

The fugacity of $\mathrm{CO}_{2}\left(f \mathrm{CO}_{2}\right)$ was computed from $\mathrm{pH}$ and total alkalinity using the software CO2SYS (Lewis, and Wallace, 1998). The carbonate dissociation constants (K1 and K2) used were those of Roy et al. (1993) as they show the best internal consistency in the low temperature waters of the Arctic Ocean when using any two of pH, DIC or TA as input parameters. The uncertainty in computed $f \mathrm{CO}_{2}$ should be in the range of 10 to $20 \mu \mathrm{atm}$ depending on which constituents were used for the computation and the precision and accuracy of the determinations (Anderson et al., 1999). The data are archived at the PANGAEA information system under the EU project European Project on Ocean Acidification (EPOCA). Atmospheric $f \mathrm{CO}_{2}$ was determined using the open-cell Licor7500 (www.licior.com).
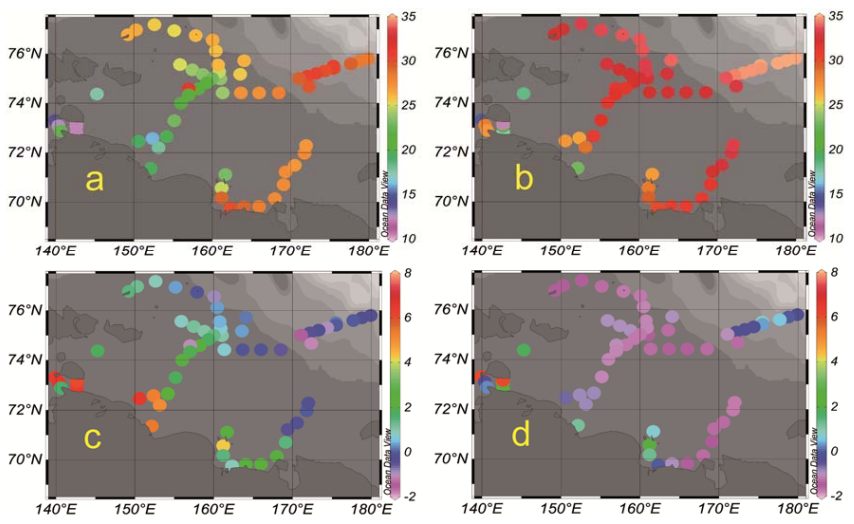

Fig. 3. The top panels show the salinity distribution in the surface water (a) and bottom water (b) while the lower panels show the temperature, ${ }^{\circ} \mathrm{C}$, distribution in the surface water (c) and bottom water (d).

For methane measurements water samples were immediately taken from Niskin bottles and poured into replicate 500$\mathrm{ml}$ glass bottles, overfilling 1.5-2 times with the sample. The headspace technique for equilibrating between the dissolved and gaseous phases was applied (Semiletov et al., 1996). Methane concentrations were measured with a MicroTech8160 gas chromatograph (GC) equipped with a flame ionization detector. The standard deviation of duplicate analyses (3-5 replicates) was less than 5\%. Details of the $\mathrm{CH}_{4}$ determination are given in Shakhova and Semiletov (2007).

\section{Results and discussion}

\subsection{Hydrography}

The sea ice coverage in the summer of 2008 was low and a large area of the ESS could be sampled (Fig. 2a). Only some small patches of drifting sea ice were observed during the cruise and restricted the sampling program (Fig. 2b). The salinity field shows generally low surface salinities in the west (below 25) and high in the east (above 25) (Fig. 3a). The low salinity water from the Laptev Sea, a result of the large runoff from the Lena River (about 4 times higher than the sum of Indigirka and Kolyma), enters the ESS along the Siberian coast and is seen all up to $75^{\circ} \mathrm{N}$ in the west with salinities in the range of 20-25 (Fig. 3a). The bottom waters in the shallow southwestern part have low salinities of the same range (Fig. 3b). The surface water temperatures show a similar pattern with the warmest water to the southwest and the coldest to the northeast (Fig. 3c).

The summer of 2008 was characterized by persistent high pressure systems in the Beaufort Sea and Wrangel Island area (Fig. 4) which resulted in generally southerly wind over the ESS. A notable period was around 2-5 September, when the observations near Kolyma River were made, with very strong 


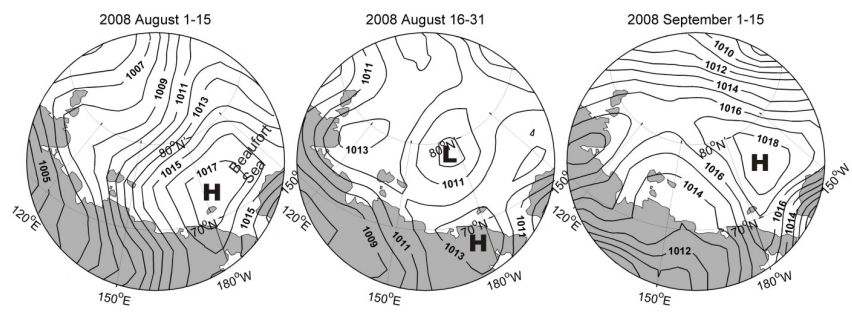

Fig. 4. Average Sea Level Pressure (SLP) during first half of August, second half of August and first half of September 2008, from National Center for Environmental Prediction (NCEP) data.

southerly wind. The offshore winds over a month prior to the expedition as well as during the expedition likely forced most of the river water offshore and also inhibited development of a confined SCC. This is reflected in the hydrographical data which generally show high surface salinity $(>25)$ in the eastern part of the ESS (east of about $160^{\circ} \mathrm{E}$ ), with no clearly represented SCC in the surface water salinity in the southeastern ESS (Fig. 3a). There are even some enhanced salinities of near 30 close to the coast at longitudes 160 to $170^{\circ} \mathrm{E}$, indicating an inflow from the Chukchi Sea. Alternatively these waters have been mixed up from the bottom (depth around $30 \mathrm{~m}$ ), but if this was the case it must have been early in the season as there is a clear signature of primary production, i.e., oxygen super-saturation as well as low nitrate and phosphate concentrations.

A large region with bottom temperatures close to the freezing point was observed (Fig. 3d). Only the waters closest to the coast line to the west are significantly warmer, likely a signature of seasonal warming in these shallow waters. The bottom waters at the continental slope are well above freezing as these have a signature of warm Atlantic Layer water (e.g., Dmitrenko et al., 2010). The high temperatures in the waters of low and high salinities as well as that the waters at freezing temperature have salinities around 32-33 are clearly seen in a $T$-S plot (Fig. 5).

\subsection{Biogeochemistry}

The river runoff also impacts the chemical signature of the waters as it has a high concentration of total alkalinity (e.g., Anderson et al., 1983; Yamamoto-Kawai et al., 2005; Pipko et al., 2010), dissolved organic carbon (e.g., Anderson, 2002; Pipko et al., 2010; Alling et al., 2011) as well as nutrients (e.g., Gordeev et al., 1999). The ISSS-08 TA data from the ESS shows a significant linear relationship with salinity with an offset at zero salinity of about $500 \mu \mathrm{mol} \mathrm{kg}{ }^{-1}$ (Fig. 6a). This is close to the $570 \pm 21 \mu \mathrm{mol} \mathrm{kg}{ }^{-1}$ reported for the offset at zero salinity in the linear relationship of TA versus salinity for waters with a salinity over 24 from the Laptev and East Siberian Seas in 1994 (Olsson and Anderson, 1997). The TA content in the runoff is a result of hydrogen carbonate ions from a combination of decay of organic matter and dis-

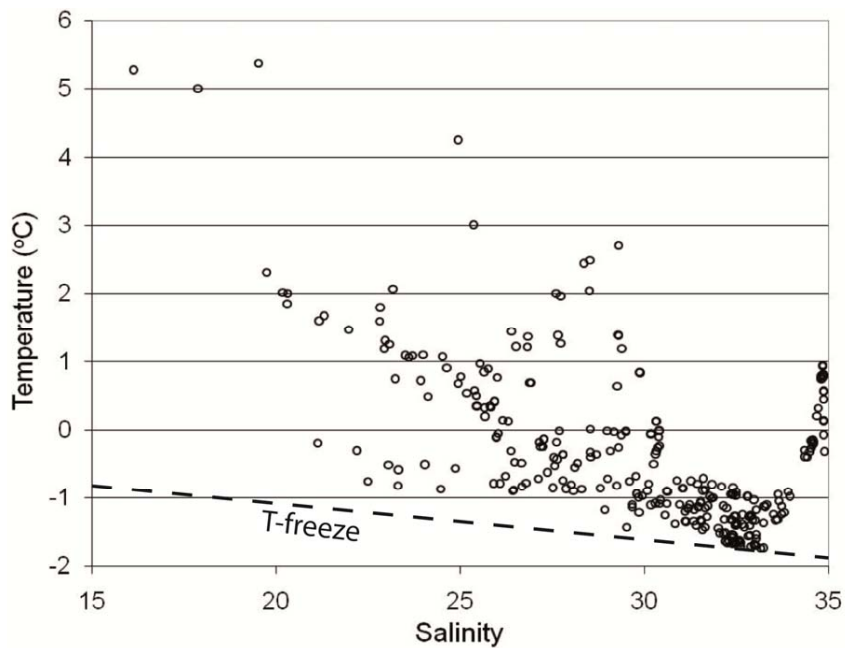

Fig. 5. Plot of temperature versus salinity. The freezing temperature as a function of salinity is illustrated by the dotted line.

solution of calcium carbonate in the drainage basins, according to the reaction $\mathrm{CH}_{2} \mathrm{O}$ (org) $+\mathrm{CaCO}_{3}(\mathrm{~s})+\mathrm{O}_{2} \rightarrow 2 \mathrm{HCO}_{3}^{-}$ $+\mathrm{Ca}^{2+}$ (e.g., Anderson et al., 2004). The linear fit (Fig. 6a) is caused by the fact that the impact on TA by biological production and decay of organic matter in oxic waters is relatively small. Note that the data presented here cannot exclude a non-conservative behavior of TA in salinities below 15, i.e., in and close to the river mouths. DIC on the other hand shows no formal conservative behavior (larger deviation from a linear fit) with concentrations on the low side of a mixing line associated with high oxygen concentrations (signature of primary production) and higher concentrations associated with low oxygen concentrations (signature of microbial decay of organic matter) (Fig. 6b). The larger deviation from a mixing line in DIC (Fig. 6b) compared to TA (Fig. 6a), implies that formation of planktons having calcium carbonate skeletons are relatively less abundant than non calcifying planktons in the study area of the ESS, especially since the TA concentration is impacted twice compared to the DIC concentration during calcium carbonate formation. It should be noted that several sources of fresh water exist in this area (different rivers as well as sea ice melt) that adds to uncertainties in this conclusion. However, the coupling of low DIC with high oxygen concentrations and vice versa support the dominance of primary production in causing the deviation from the mixing line of Fig. $6 \mathrm{~b}$.

The oxygen saturation in the surface waters with a deficit in DIC (i.e., under-saturated with respect to $f \mathrm{CO}_{2}$ ) are typically between 100 and $110 \%$, but higher oversaturation, up to $\sim 130 \%$, is observed at about $20 \mathrm{~m}$ depth. This subsurface maximum in oxygen saturation was also observed by Codispoti and Richards (1971), which they attributed to in situ photosynthesis production in well stratified waters. The oxygen saturation in the waters of excess DIC was as low as $<40 \%$, 

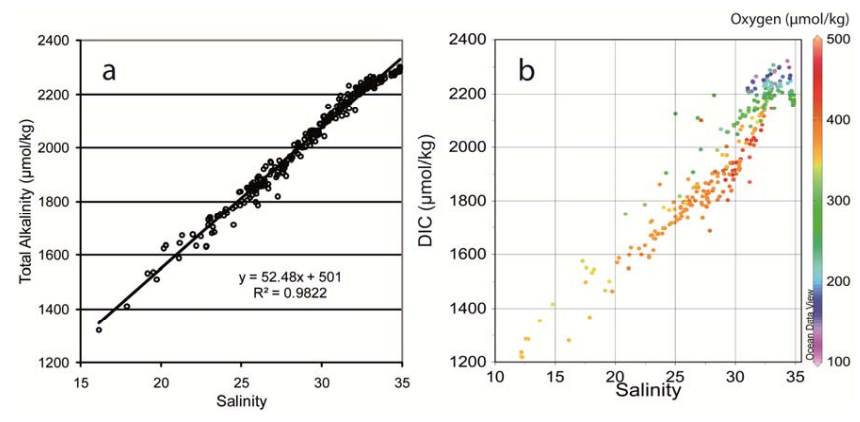

Fig. 6. Total alkalinity (a) and total dissolved inorganic carbon (b) versus salinity, where the latter is colored by the oxygen concentration.

and these waters were found close to the bottom. However, no water samples were collected directly at the sediment water interface and thus it is possible that even lower oxygen saturation values than the observed were present.

Biogeochemical transformation is even more obvious in plots of the nutrients and $f \mathrm{CO}_{2}$ versus salinity (Fig. 7). A common feature for these parameters is the high values in the salinity range 32-33, the range with near freezing water temperatures. These high values are a signal of mineralization of organic matter, likely occurring at the sediment surface with the decay products released to the cold bottom water (Fig. 3d). The highest salinities are found in the deep water at the shelf break stations and they have significantly lower nutrient concentrations, all consistent with these waters being of Atlantic origin circulating along the continental slope of the deep central Arctic Ocean (Rudels et al., 1994). Waters having salinities below $\sim 32$ show much more diverse signatures, with a wide span of nutrient concentrations as well as $f \mathrm{CO}_{2}$ values. The lowest $f \mathrm{CO}_{2}$ values (at salinities between about 27 and 32) are mostly found in the surface and subsurface waters to the north and east of the ESS. This is a signature of recent primary production, consuming $\mathrm{CO}_{2}$ as well as nutrients. The very low salinities, below $\sim 23$, is found in the southwestern region. Here the $f \mathrm{CO}_{2}$ is at or above the atmospheric values at the time of the study which were in the range 375 to $380 \mu$ atm (A. N. Salyuk, Pacific Oceanological Institute, personal communication, 2010).

Oversaturation of $\mathrm{CO}_{2}$ shows that heterotrophic activity exceeds that of autotrophic in these waters: In marine waters the phosphate and nitrate concentration will normally increase when heterotrophy dominates, but this is not directly reflected in the nutrient distribution (Fig. 7a-c) since the concentration in this area also is impacted by the mixing with river runoff. At the low salinity waters, below $\sim 20$, there is a signal of nutrient consumption by marine primary production and the water is oversaturated with respect to $\mathrm{CO}_{2}$. The nutrient consumption is most pronounced for phosphate as the observed concentrations cannot be achieved by mixing of the two observed water masses, one being seawater with a phos-
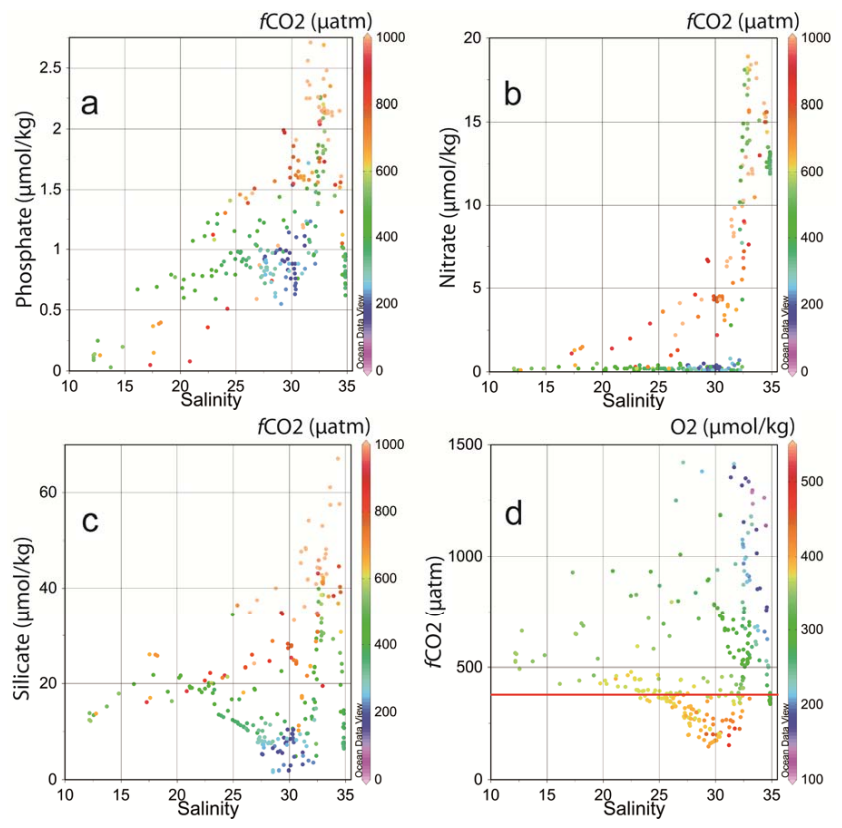

Fig. 7. Plots of phosphate (a), nitrate (b) silicate (c) and $f \mathrm{CO}_{2}$ (d) versus salinity for all samples collected in the East Siberian Sea. The color symbols in the nutrient plots illustrate the $f \mathrm{CO}_{2}$ values, while the color in the $f \mathrm{CO}_{2}$ plot illustrate the oxygen concentration. In the latter the atmospheric level at the time of the investigation is illustrated with the horizontal line at 375-385 $\mu$ atm.

phate concentration of $\sim 1 \mu \mathrm{mol} \mathrm{kg}-1$ at $S=25$, the other being runoff even if it has no phosphate. The most plausible explanation of the pattern in nutrient and $f \mathrm{CO}_{2}$ signature is that microbial decay of terrestrial organic matter, low in nutrients, is dominating over marine primary production when it comes to carbon transformation (Anderson et al., 2009).

In the salinity range of about 27-32 there is a signal of draw down of phosphate and silicate in the waters with low $f \mathrm{CO}_{2}$ values relative to those at atmospheric equilibrium, indicating primary production. For nitrate this feature is less obvious, largely because of the many samples with close to zero concentration. Ammonium can also be used as a nitrogen source in primary production. Unfortunately ammonium was not determined on board the Yacob Smirnitskyi, but some samples were brought home and analyzed in the laboratory. The quality of these data was not good and is thus not presented in this contribution. However, the majority of the samples from the upper waters had concentrations at the detection limit, indicating that ammonium was of minor importance in this depth range. Hence nitrate is the limiting factor for marine primary production in these waters. 

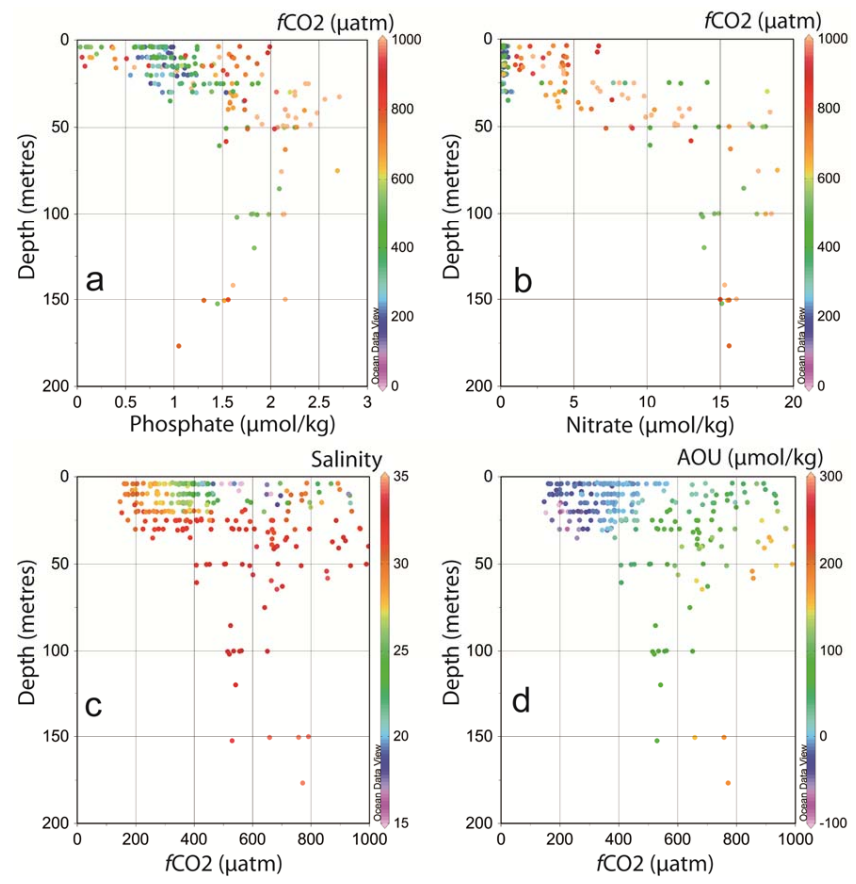

Fig. 8. Depth profiles of phosphate (a), nitrate (b), both color coded by $f \mathrm{CO}_{2}$, and $f \mathrm{CO}_{2}$ color coded by salinity (c) and by AOU (d).

\subsubsection{Primary production}

The waters with $f \mathrm{CO}_{2}$ below atmospheric values, and salinities between 25 and 32 (Fig. 7d) are the only ones where net autotrophic conditions prevail. These conditions are found in the surface waters of the northern and eastern ESS (Fig. 3a). A depth plot of $f \mathrm{CO}_{2}$ color coded for salinity (Fig. 8c) confirms this and shows that the waters of $f \mathrm{CO}_{2}$ below those of the atmosphere are confined to the upper $\sim 30 \mathrm{~m}$. The color coding for Apparent Oxygen Utilization (AOU) (Fig. 8d) supports this conclusion by its negative AOU values for waters of under-saturated $f \mathrm{CO}_{2}$. The nutrient signal is less straightforward (Fig. 8a, b), with phosphate concentrations in the range 0.7 to $1.2 \mu \mathrm{mol} \mathrm{kg}^{-1}$ for waters being undersaturated in $f \mathrm{CO}_{2}$. Nitrate on the other hand is very close to zero for these waters. However, there are upper waters (shallower than $30 \mathrm{~m}$ ) with higher concentrations in both phosphate and nitrate, as well as lower in phosphate, but these are all found in the southwestern ESS. It is clear, though, that nitrate is the limiting nutrient in the eastern ESS.

From the $f \mathrm{CO}_{2}$ profile (Fig. 8c, d) it is seen that large variability exist within the ESS, but the minimum value is about $175 \mu \mathrm{atm}$ which means a maximum under-saturation of about $200 \mu \mathrm{atm}$. For the 22 stations to the east of $165^{\circ}$ and north of $70^{\circ}$ the variability in the $f \mathrm{CO}_{2}$ gets less with average values for the depth intervals $0-10,10-20$, and $20-30 \mathrm{~m}$ being $298 \pm 68,291 \pm 73$ and $349 \pm 132 \mu$ atm, respectively. Hence, the under-saturation relative to the atmospheric values are confined to waters shallower than a depth range of
20 to $30 \mathrm{~m}$ depending on the station location. Computing the DIC deficit relative to a $f \mathrm{CO}_{2}$ of $385 \mu \mathrm{atm}$ (atmospheric level) at the observed $S, T$ and TA equals $35 \pm 35,37 \pm 43$, and $19 \pm 86 \mu \mathrm{mol} \mathrm{kg}^{-1}$, for the $-10,10-20$, and $20-30 \mathrm{~m}$ depth intervals. Assuming that the water was at equilibrium with $385 \mu \mathrm{atm} f \mathrm{CO}_{2}$ in the start if the productive season the primary production has consumed the corresponding amount which equals on the average $36 \pm 56 \mu \mathrm{mol} \mathrm{kg}{ }^{-1}$ in the top $20 \mathrm{~m}$ or $30 \pm 103 \mu \mathrm{mol} \mathrm{kg}^{-1}$ in the top $30 \mathrm{~m}$. Applying the Redfield ratio of P:N:C of 1:16:106 means a consumption of about $0.3 \mu \mathrm{mol} \mathrm{kg}-1$ and $5 \mu \mathrm{mol} \mathrm{kg}{ }^{-1}$ of phosphate and nitrate, respectively. These values are in the range of all data in the top $30 \mathrm{~m}$ of Fig. 8a, b, making this a realistic consumption. However, the exact nutrient concentrations in these waters before productivity started are not known and thus it is not possible to prove this carbon draw down from nutrient data.

Integrating the DIC consumptions $36 \pm 56 \mu \mathrm{mol} \mathrm{kg}{ }^{-1}$ over $20 \mathrm{~m}$ or $30 \pm 103 \mu \mathrm{mol} \mathrm{kg}{ }^{-1}$ over $30 \mathrm{~m}$ depth results in consumptions of $0.7 \pm 1$ and $0.9 \pm 3 \mathrm{~mol} \mathrm{C} \mathrm{m}^{-2}$, respectively, and the new primary production should thus be in this range. As seen these values have large uncertainties, all from zero to up to about 3 times the values when integrating to $30 \mathrm{~m}$. This consumption is restricted to the area of the ESS with $S>\sim$ 25, which according to the surface salinity map (Fig. 3a) is about half of the ESS. Assuming that an annual consumption of $0.8 \pm 2 \mathrm{~mol} \mathrm{C} \mathrm{m}^{-2}$ is valid for half of the ESS, with an area of $\sim 500000 \mathrm{~km}^{2}$, gives an annual primary production of 0.4 $( \pm 1) \times 10^{12} \mathrm{molC}$ or $\sim 4( \pm 10) \times 10^{12} \mathrm{gC}$, with the mean being 2.5 to 3.5 times lower than previous estimations: 10 $15 \times 10^{12} \mathrm{gC}$ (Vetrov and Romankevich, 2004; Vinogradov et al., 2000). However, considering the uncertainties the difference between $4( \pm 10) \times 10^{12} \mathrm{gC}$ and $10-15 \times 10^{12} \mathrm{gC}$ is not significant. Furthermore an aerial estimate of new production equaling $10 \mathrm{gC}\left(\mathrm{m}^{-2} \mathrm{yr}^{-1}\right)$ is in close agreement of estimates for other interior Arctic Ocean shelves like the Kara, Laptev and Beaufort Seas (Sakshaug, 2004; Carmack et al., 2006). However, our study show that this productivity is not relevant for the whole ESS which has to be considered when estimating the total new productivity of this region.

\subsubsection{Fate of organic matter}

Microbial degradation of organic matter occurs at the sediment surface, which impacts the chemical environment of the bottom waters of the ESS (Fig. 9). The lowest oxygen concentration is observed in a region centered at about $73^{\circ} \mathrm{N}$ and $155^{\circ} \mathrm{E}$. In the same region the lowest $\mathrm{pH}$ and the highest $f \mathrm{CO}_{2}$ values are observed. However, the highest nutrient concentrations have a slightly different areal distribution. The maximum phosphate concentration is found somewhat to the north of the region of the minimum oxygen and $\mathrm{pH}$ values, as well as in a region in the eastern ESS. In the latter region the highest nitrate concentrations are also observed. This overall pattern is likely the result of different sources of 

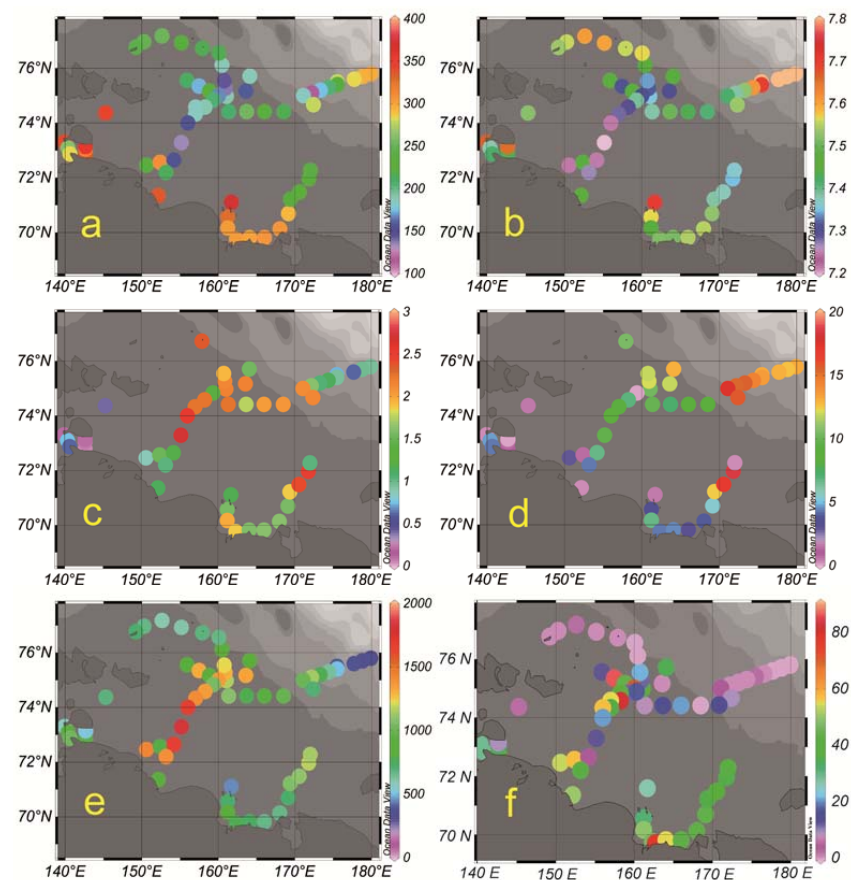

Fig. 9. Distribution of oxygen, $\mu \mathrm{mol} \mathrm{kg}-1$ (a), $\mathrm{pH}$, seawater scale at $15^{\circ} \mathrm{C}$ (b), phosphate, $\mu$ mol kg${ }^{-1}$ (c), nitrate, $\mu \mathrm{mol} \mathrm{kg}{ }^{-1}$ (d), $f \mathrm{CO}_{2}$, $\mu$ atm (e) and $\mathrm{CH}_{4}, \mathrm{nM}$ (f) in the bottom waters of the ESS.

the degraded organic matter (OM). Terrestrial OM that is low in nutrients dominates in the western ESS, while degradation of marine OM dominates in the northern and eastern ESS. Such a pattern is supported by the $\delta^{13} \mathrm{C}$ signature of $\mathrm{OM}$ in the particulate material, POM and in the sediment (Naidu et al., 2000; Semiletov et al., 2005), and molecular and radiocarbon in the POM along the Kolyma paleoriver transect (Vonk et al., 2010).

Another possible product of microbial decay of organic matter is methane $\left(\mathrm{CH}_{4}\right)$, when $\mathrm{CO}_{2}$ itself is used as electron acceptor. In marine environment modern methanogenesis can occur at very low levels in strictly anaerobic sediments, where sulfate concentration is low, or in the anaerobic lenses that might at places occur in the pycnocline (Damm et al., 2005). In the ESS, such production is limited to the Holocene sediment layer accumulated above the sub-sea permafrost, which caps deeper sediments. This means that modern methanogenesis can only take place within the taliks (layers of thawed sediments within the permafrost body) and/or in areas of preferential sediment accumulation, primarily in water depths greater than $50 \mathrm{~m}$.

In the ESS methane is found in largely variable concentrations. In some areas of the ESS surface water is up to 20 times super-saturated in $\mathrm{CH}_{4}$ relative to the atmosphere, while mid- and bottom waters are supersaturated by up to 400 times (Shakhova et al., 2010a, b). High dissolved $\mathrm{CH}_{4}$ concentrations, up to $\sim 60 \mathrm{nM}$ were found in the bottom water along the Indigirka paleo-valley, between $150^{\circ} \mathrm{E}$ and $155^{\circ} \mathrm{E}$,
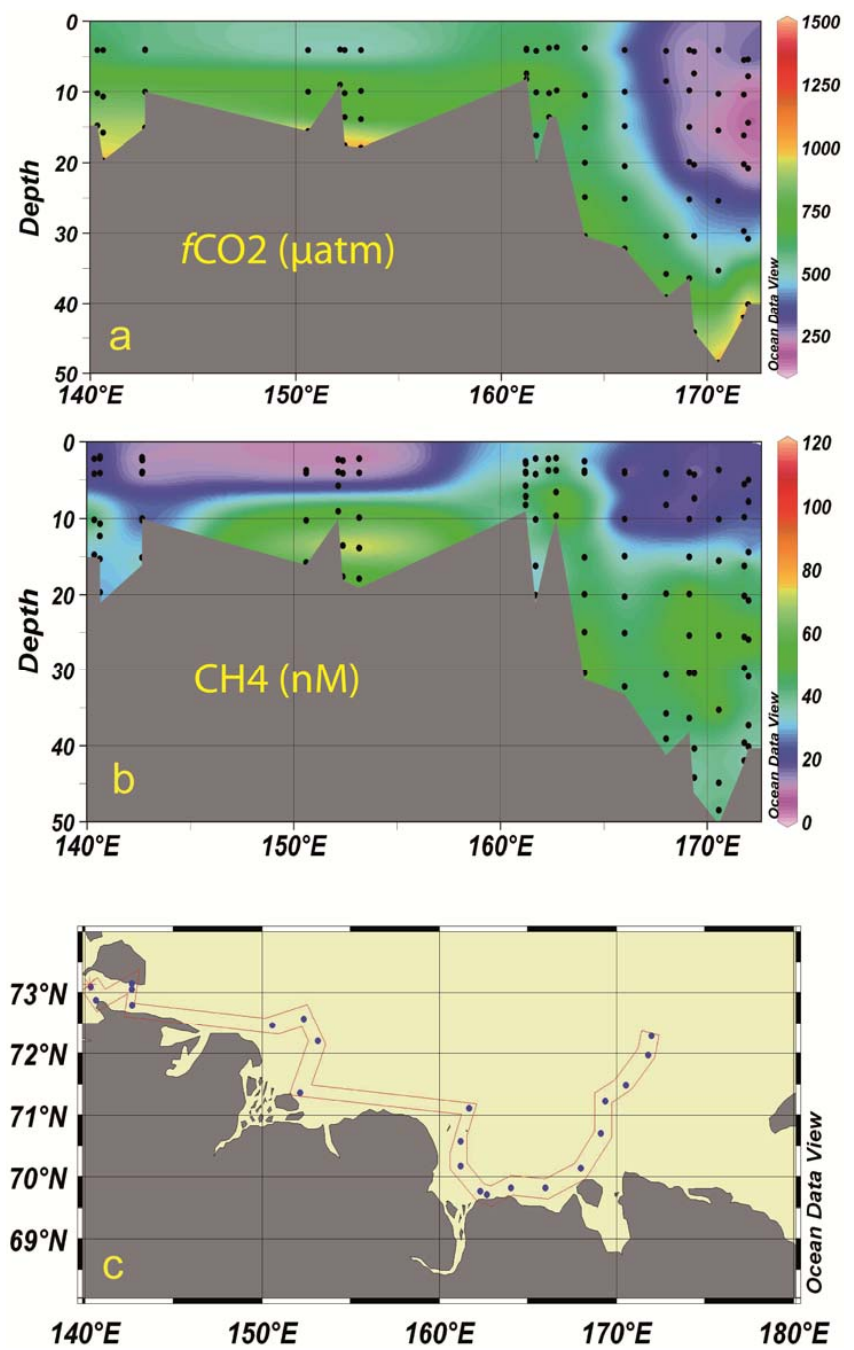

Fig. 10. Distribution of $f \mathrm{CO}_{2}$ (a) and dissolved $\mathrm{CH}_{4}$ (b) at the "alongshore" transect (c) in the summer 2008.

and along the shallow transect east of the Kolyma mouth, between $160^{\circ} \mathrm{E}$ and $165^{\circ} \mathrm{E}$ (Fig. 9f). The $\mathrm{CH}_{4}$ concentration distribution is primarily determined by sediment sources and not as much by the water mass sources and circulation as $f \mathrm{CO}_{2}$ is (Fig. 10). For the latter the largest gradients is found in the frontal zone between the low saline and lowtransparent heterotrophic local shelf waters and the high productive and high-transparent Pacific-derived autotrophic waters (Pipko et al., 2005, 2008, 2011; Semiletov et al., 2005, 2007). The dissolved $\mathrm{CH}_{4}$ concentration is mostly related to the location of seabed $\mathrm{CH}_{4}$ sources inside the fault zones and through taliks (Nikolsky and Shakhova, 2010; Shakhova et al., 2010a, b). In general, the concentrations of dissolved $\mathrm{CH}_{4}$ determined in 2008 are similar to those measured in 2003. 

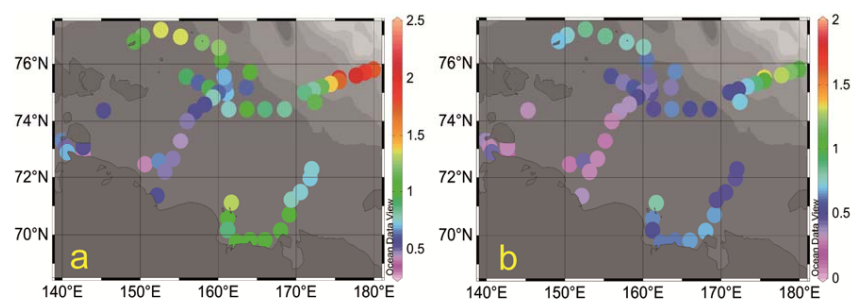

Fig. 11. Distribution of the saturation state of calcite (a) and aragonite (b) in the bottom waters of the ESS, expressed as omega $\left(\left[\mathrm{Ca}^{2+}\right]\left[\mathrm{CO}_{3}^{2-}\right] / \mathrm{K}_{\mathrm{SO}}\right)$. In both figures saturation is colored green.

\subsection{Impact on ocean $\mathbf{p H}$}

The low $\mathrm{pH}$ caused by microbial decay of organic matter results in a drift of the dissolved carbonate system from carbonate ions to carbonic acid. This in turn will decrease the solubility state of calcium carbonate, typically expressed as omega $\left(\Omega=\left[\mathrm{Ca}^{2+}\right]\left[\mathrm{CO}_{3}^{2-}\right] / \mathrm{K}_{\mathrm{SO}}\right)$ where $\mathrm{K}_{\mathrm{SO}}$ is the chemical solubility product of $\mathrm{CaCO}_{3}$. Omega will be further decreased by dilution with river runoff, the latter of which has a lower calcium ion concentration than seawater. These conditions have a profound impact on the saturation state of calcite and aragonite in the bottom waters of the ESS (Fig. 11). The western part is strongly under-saturated with respect to both calcite and aragonite. Most of the rest of the area investigated during the ISSS-08 is under-saturated with respect to aragonite and close to saturation or slightly under-saturated also with respect to calcite. These conditions make the living conditions for benthic calcifiers very unfavorable.

Whether the situation has been like this for many years or if it has been "acidified" during later years as a result of both an increased load of terrestrial $\mathrm{OM}$ as well as increased atmospheric partial pressure of $\mathrm{CO}_{2}$ cannot be concluded from these data. However, in a shallow sea like the ESS the atmospheric signature will penetrate to the bottom within a very short time, maximum a few years.

\section{Summary and conclusions}

A comprehensive data set of physical and chemical data, covering a large area of the East Siberian Sea, illustrates the substantial biogeochemical transformation that occurs in this region. The data confirm that two governing hydrographic regimes exist, one in the west which is dominated by an influence of river runoff and one in the east which is dominated by modified water from the Pacific Ocean. In these two regimes different biogeochemical processes rule, with heterotrophic activity exceeding that of autotrophic in the west, resulting in over-saturation of $\mathrm{CO}_{2}$, and the opposite in the surface waters to the east, i.e., under-saturation of $\mathrm{CO}_{2}$. The bottom waters are all high in nutrients and $f \mathrm{CO}_{2}$, with extremely high values in the central western ESS. Here the $f \mathrm{CO}_{2}$ val- ues were well above $1000 \mu$ atm and this, in combination with high nutrient and low oxygen concentrations shows extensive microbial decay of organic matter. The origin of the organic matter is both marine primary production and input of terrestrial organic matter, where the latter dominates in the surface waters to the west, as deduced from the nutrient distribution. Another signature of microbial decay of organic matter could be methane. The observations showed a high-spatial variability of dissolved $\mathrm{CH}_{4}$, confirming earlier observations of a source from the seabed of possibly both glacial and modern production of methane.

From the depth profiles of the carbon system parameters it was possible to infer a quantitative estimate of primary production. The under-saturation of $f \mathrm{CO}_{2}$ corresponds to a DIC consumption that when integrated over 20 to $30 \mathrm{~m}$ depth results in a consumption of 0.7 to $0.9 \mathrm{~mol} \mathrm{C} \mathrm{m}^{-2}$. Assuming surface water at saturation in the spring when production starts gives an estimate of a corresponding areal productivity. The under-saturation was observed in about half of the ESS, estimated area of $\sim 500000 \mathrm{~km}^{2}$, giving an annual primary production of $0.4 \times 10^{12} \mathrm{~mol} \mathrm{C}$ or $\sim 4 \times 10^{12} \mathrm{gC}$. However, these numbers have substantial uncertainties.

The decay of organic matter at the sediment surface that results in the high $f \mathrm{CO}_{2}$ levels also lowers $\mathrm{pH}$. Values below 7.5 units, $\mathrm{pH}^{\mathrm{sw}}$ normalized to $15^{\circ} \mathrm{C}$, were observed making this one of the most naturally acidified open marine environments. The anthropogenic ocean acidification signal will in a short time penetrate all through the water column in these shallow seas of about $50 \mathrm{~m}$ bottom depth. Calcium carbonate is under-saturated especially with respect to aragonite. Consequently, the conditions for calcifying organisms are not favorable. This is in line with observations of TA which show conservative behavior and thus little formation or dissolution of $\mathrm{CaCO}_{3}$ seems to occur.

Acknowledgements. This work was carried out with logistic support from the Knut and Alice Wallenberg Foundation and from Swedish Polar research Secretariat. The science was financially supported by; the Swedish Research Council (contract no. 621-2006-3240 and 621-2010-4084); the European Union projects, CarboOcean (contract no. 511176-2), EPOCA (contract 211384) and DAMOCLES (contract 018509); the Far-Eastern Branch of the Russian Academy of Sciences (FEBRAS); the NOAA OAR Climate Program Office (NA08OAR4600758); the U.S. National Science Foundation (Nos. ARC-1023281 (NS \& IS) and ARC-0909546 (IS\&NS)); and the Russian Foundation for Basic Research (No. 04-05-64819, 10-05-00996- (IPS), No. 05-05-64213, 08-05-00184 (IIP)). We are also grateful to all our colleagues that contributed to the implementation of the project.

Edited by: Ö. Gustafsson 


\section{References}

Alling, V., Sanchez-Garcia, L., Porcelli, D., Pugach, S., Vonk, J., van Dongen, B., Mörth, M., Anderson, L.G., Sokolov, A., Humborg, C., Semiletov, I., and Gustafsson, Ö.: Non-conservative behavior of dissolved organic carbon across the Laptev and East Siberian Seas, Global Biogeochem. Cy., 24, GB4033, doi:10.1029/2010GB003834, 2010.

Anderson, L., Dyrssen, D., Jones, E. P., and Lowings, M. G.: Inputs and outputs of salt, fresh water, alkalinity and silica in the Arctic Ocean, Deep-Sea. Res., 30, 87-94, 1983.

Anderson, L. G., Turner, D. R., Wedborg, M., and Dyrssen, D.: Determination of total alkalinity and total dissolved inorganic carbon, in: Methods of Seawater Analysis, third edition, edited by: Kremling, K. and Ehrhardt, M. VCH, Weinheim, Germany, 127$148,1999$.

Anderson, L. G.: DOC in the Arctic Ocean, in: Biogeochemistry of Marine Dissolved Organic Matter, edited by: Hansell, D. A. and Carlson, C. A., Academic Press, 665-683, 2002.

Anderson, L. G., Jutterström, S., Kaltin, S., Jones, E. P., and Björk, G.: Variability in river runoff distribution in the Eurasian Basin of the Arctic Ocean, J. Geophys. Res., 109, C01016, doi:10.1029/2003JC001773, 2004.

Anderson, L. G., Jutterström, S., Hjalmarsson, S., Wåhlström, I., and Semiletov, I. P.: Out-gassing of $\mathrm{CO}_{2}$ from Siberian Shelf Seas by terrestrial organic matter decomposition, Geophys. Res. Lett., 36, L20601, doi:10.1029/2009GL040046, 2009.

Carmack, E., Barber, D., Christensen, J., Macdonald, R., Rudels, B., and Sakshaug, E.: Climate variability and physical forcing of the food webs and the carbon budget on panarctic shelves, Prog. Ocean., 71, 145-182, 2006.

Clayton, T. D. and Byrne, R. H.: Spectrophotometric seawater $\mathrm{pH}$ measurements: total hydrogen ion concentration scale calibration of m-cresol purple and at-sea results, Deep-Sea Res.Pt. I, 40, 2115-2129, 1993.

Codispoti, L. A. and Richards, F. A.: Micronutrient distributions in the East Siberian and Laptev seas during summer 1963, Arctic, 21, 67-83, 1968.

Codispoti, L. A. and Richards, F. A.: Oxygen supersaturations in the Chukchi and East Siberian Seas, Deep-Sea Res., 18, 341351, 1971.

Damm, E., Mackensen, A., Budeus, G., Faber, E., and Hanfland, C.: Pathways of methane in seawater: Plume spreading in an Arctic shelf environment (SW-Spitsbergen), Cont. Shelf Res., 25, 1453-1472, 2005.

Dmitrenko, I., Kirillov, S., Eicken, H., and Markova, N.: Winddriven summer surface hydrography of the eastern Siberian shelf, Geophys. Res. Lett., 32, L14613, doi:10.1029/2005GL023022, 2005.

Dmitrenko, I. A., Kirillov, S. A., and Tremblay, L. B.: The longterm and interannual variability of summer fresh water storage over the eastern Siberian shelf: Implication for climatic change, J. Geophys. Res., 113, C03007, doi:10.1029/2007JC004304, 2008.

Dmitrenko, I. A., Kirillov, S. A., Tremblay, L. B., Bauch, D., Hölemann, J.A., Krumpen, T., Kassens, H., Wegner, C., Heinemann, G., and Schröder, D.: Impact of the Arctic Ocean Atlantic water layer on Siberian shelf hydrography, J. Geophys. Res., 115, C08010, doi:10.1029/2009JC006020, 2010.
Gordeev, V. V., Dzhamalov, R. G., Zektser, I. S., Zhulidov, V. V., and Bryzgalo, V. A.: Assessment of nutrient discharge with river and groundwater flow into marginal seas of the Russian Arctic Regions, Water Resour., 26, 2, 181-186, 1999.

Haraldsson, C., Anderson, L. G., Hassellöv, M., Hulth, S., and Olsson, K.: Rapid, high-precision potentiometric titration of alkalinity in the ocean and sediment pore waters, Deep-Sea Res. Pt. I, 44, 2031-2044, 1997.

Holt, B. and Martin, S.: The effect of a storm on the 1992 summer sea ice cover of the Beaufort, Chukchi, and East Siberian Seas, J. Geophys. Res., 106(C1), 1017-1032, 2001.

Jakobsson, M.: Hypsometry and volume of the Arctic Ocean and its constituent seas, Geochem. Geophys. Geosyst., 3(5), doi:10.1029/2001GC000302, 2002.

Johnson, K. M., Sieburth, J. M., Williams, P. J., and Brändström, L.: Coulometric total carbon dioxide analysis for marine studies: automation and calibration, Mar. Chem., 21, 117-133, 1987.

Khim, B.-K., Krantz, D. E., Cooper, L. W., and Grebmeier, J. M.: Seasonal discharge of estuarine freshwater to the western Chukchi Sea shelf identified in stable isotope profiles of mollusk shells, J. Geophys. Res., 108(C9), 3300, doi:10.1029/2003JC001816, 2003.

Kwok, R., Cunningham, G. F., Wensnahan, M., Rigor, I., Zwally, H. J., and Yi D.: Thinning and volume loss of the Arctic Ocean sea ice cover: 2003-2008, J. Geophys. Res., 114, C07005, doi:10.1029/2009JC005312, 2009.

Lee K. and Millero, F. J.: Thermodynamic studies of the carbonate system in seawater, Deep-Sea Res. Pt. I, 42, 2035-2061, 1995.

Lewis, E. and Wallace, D. W. R.: Program developed for $\mathrm{CO}_{2}$ system calculations. ORNL/CDIAC-105. Carbon Dioxide Information Analysis Center, Oak Ridge National Laboratory, U.S. Department of Energy, Oak Ridge, Tennessee, 1998.

Morris, K., Li, S. S., and Jeffries, M.: Meso- and microscale sea-ice motion in the East Siberian Sea as determined from ERS-1 SAR data, J. Glaciol., 45, 150, 370-382, 1999.

Naidu, A. S., Cooper, L. W., Finney, B. P., Macdonald, R. W., Alexander, C., and Semiletov, I. P.: Organic carbon isotope ratios $(\delta 13 \mathrm{C})$ of Arctic Amerasian continental shelf sediments, Int. J. Earth Sci., 89, 522-532, 2000.

Nghiem, S. V., Chao, Y., Neumann, G., Li, P., Perovich, D. K., Street, T., and Clemente-Colón P.: Depletion of perennial sea ice in the East Arctic Ocean, Geophys. Res. Lett., 33, L17501, doi:10.1029/2006GL027198, 2006.

Nicolsky, D. and Shakhova, N.: Modeling sub-sea permafrost in the East-Siberian Arctic Shelf: the Dmitry Laptev Strait, Environ Res. Lett., 5, doi:10.1088/1748-9326/5/1/015006, 2010.

Olsson, K. and Anderson, L. G.: Input and biogeochemical transformation of dissolved carbon in the Siberian shelf seas, Cont. Shelf Res., 17, 819-833, 1997.

Pipko, I. I., Semiletov, I. P., and Pugach, S. P.: The carbonate system of the East Siberian Sea waters, Doklady Earth Sciences, 402, 4, 624-627, 2005.

Pipko, I. I., Semiletov, I. P., Tichshenko, P. Ya., Pugach, S. P., and Savel'eva, N. I.: Variability of the carbonate system parameters in the coast-shelf zone of the East Siberian Sea during the autumn season, (translated to English), Oceanology, 48(1), 54-67, 2008.

Pipko, I. I., Pugach, S. P., Dudarev, O. V., Charkin, A. N., and Semiletov, I. P.: Carbonate parameters of the Lena River: Char- 
acteristics and Distribution, Geochemistry Int., 48(11), 11311137, 2010.

Pipko, I. I., Semiletov, I. P., Pugach, S. P., Wåhlström, I., and Anderson, L. G.: Interannual variability of air-sea $\mathrm{CO}_{2}$ fluxes and carbonate system parameters in the East Siberian Sea, Biogeosciences Discuss., 8, 1227-1273, doi:10.5194/bgd-8-1227-2011, 2011.

Polyakov, I. V., Alexeev, V. A., Belchansky, G. I., Dmitrenko, I. A., Ivanov, V. V., Kirillov, S. A., Korablev, A. A., Steele, M., Timokhov, L. A., and Yashayaev, I.: Arctic Ocean freshwater changes over the past 100 years and their causes, J. Climate, 21(2), 364384, doi:10.1175/2007JCLI1748.1, 2008.

Roy, R. N., Roy, L. N., Vogel, K. M., Porter-Moore, C., Pearson, T., Good, C. E., Millero, F. J., and Campbell, D. M.: The dissociation constants of carbonic acid in seawater at salinities 5 to 45 and temperatures 0 to 46 deg C., Mar. Chem., 44, 249-267, 1993.

Rudels, B., Jones, E. P., Anderson L. G., and Kattner, G.: On the intermediate depth waters of the Arctic Ocean, in: The Polar Oceans and Their Role in Shaping the Global Environment, edited by: Johannessen, O. M., Muench, R. D. and Overland, J. E., American Geophysical Union, Washington, D.C., 33-46, 1994.

Sakshaug, E.: Primary and secondary production in the Arctic seas, in: The Organic Carbon Cycle in the Arctic Ocean, edited by: Stein, R. and Macdonald, R. W., Springer, New York, 57-81, 2004.

Savel'eva, N. I., Semiletov, I. P., and Pipko, I. I.: Impact of synoptic processes and river discharge on the thermohaline structure in the East Siberian Shelf, (translated to English), Russian Met. Hydrol., 33(4), 240-246, 2008.

Semiletov, I. P., Pipko, I. I., Pivovarov, N. Y., Popov, V. V., Zimov, S. A., Voropaev, Yu. V., and Daviodov, S. P.: Atmospheric carbon emission from North Asian Lakes: a factor of global significance, Atmos Environ., 30(10/11), 1657-1671, 1996.

Semiletov, I., Dudarev, O., Luchin, V., Charkin, A., Shin, K.-H., and Tanaka, N.: The East Siberian Sea as a transition zone between Pacific-derived waters and Arctic shelf waters, Geophys. Res. Lett., 32, L10614, doi:10.1029/2005GL022490, 2005.
Semiletov, I. P., Pipko, I. I., Repina, I., and Shakhova, N. E.: Carbonate chemistry dynamics and carbon dioxide fluxes across the atmosphere-ice-water interfaces in the Arctic Ocean: Pacific sector of the Arctic, J. Mar. Syst., 66, 204-226, 2007.

Shakhova, N. and Semiletov, I.: Methane release and coastal environment in the East Siberian Arctic shelf, J. Mar. Syst., 66, 227-243, 2007.

Shakhova, N., Semiletov, I., Salyuk, A., Joussupov, V., Kosmach, D., and Gustafsson, Ö.: Extensive methane venting to the atmosphere from sediments of the East Siberian Arctic Shelf, Science 327, 1246-1250, 2010a.

Shakhova, N., Semiletov, I., Leifer, I., Rekant, P., Salyuk, A., and Kosmach, D.: Geochemical and geophysical evidence of methane release from the inner East Siberian Shelf, J. Geophys. Res., 115, doi:10.1029/2009JC005602, 2010b.

Spreen, G., Kaleschke, L., and Heygster, G., Sea ice remote sensing using AMSR-E $89 \mathrm{GHz}$ channels, J. Geophys. Res., doi:10.1029/2005JC003384, 2008.

Steele, M. and Ermold, W.: Salinity trends on the Siberian shelves, Geophys. Res. Lett., 31, L24308, doi:10.1029/2004GL021302, 2004.

Vetrov, A. A. and Romankevich, E. A.: Carbon cycle in the Russian Arctic seas, Berlin, Springer Verlag, 331 p., 2004.

Vinogradov, M. E., Vedernikov, V. I., Romankevich, E. A., and Vetrov, A. A.: Some components of carbon cycle in the Russian Arctic seas, Oceanology, 40, 2, 221-233, 2000.

Vonk, J. E., Sánchez-García, L., Semiletov, I., Dudarev, O., Eglinton, T., Andersson, A., and Gustafsson, Ö.: Molecular and radiocarbon constraints on sources and degradation of terrestrial organic carbon along the Kolyma paleoriver transect, East Siberian Sea, Biogeosciences, 7, 3153-3166, doi:10.5194/bg-73153-2010, 2010.

Weingartner, T. J., Danielson, S., Sasaki, Y., Pavlov, V., and Kulakov M. I.: The Siberian Coastal Current: A windand buoyancy-forced Arctic coastal current, J. Geophys. Res., 104(C12), 29697-29713, 1999.

Yamamoto-Kawai, M., Tanaka, N., and Pivovarov, S.: Freshwater and brine behaviors in the Arctic Ocean deduced from historical data of $\mathrm{d}^{18} \mathrm{O}$ and alkalinity (1929-2002 A.D.), J. Geophys. Res., 110, C10003, doi:10.1029/2004JC002793, 2005. 